\title{
The Productivity Forecasting in the Sector of Non-Market Services (Education and Health Care sectors): a Case Study of Ukraine
}

\author{
Svitlana Kozhemiakina 1[0000-0002-1314-0841], Liudmyla Ilich 2[0000-0002-8594-1824], \\ Olha Ilyash 3[0000-0002-7882-3942], Svitlana Hrynkevych 4[0000-0002-3563-3989], \\ Svitlana Kruvysha 5[0000-0002-8796-8764] \\ 1,2 Borys Grinchenko Kyiv University, Kyiv, Ukraine, \\ s.kozhemiakina@kubg.edu.ua,l.ilich@kubg.edu.ua, \\ 3 International University of Finance, National Technical University of Ukraine "Igor \\ Sikorsky Kyiv Polytechnic Institute”, Kyiv, Ukraine, WSG University of Economy in \\ Bydgoszcz, Poland, olha.ilyash@byd.pl, \\ 4 Lviv Polytechnic National University, Kyiv, Ukraine, \\ svitlana.s.hrynkevych@lpnu.ua, \\ sKyiv Regional Employment Center, Kyiv, Ukraine \\ svekrivusha@meta.ua
}

\begin{abstract}
Strategic documents lack forecast indicators of the productivity of such nonmarket sectors of the economy as education and health care; therefore, it significantly limits the possibilities of state influence on the efficiency of activities, which is common in international practice. In the article3, the scientific hypotheses have been
\end{abstract}

generalized. The correlation analysis since the process of forecasting the development of basic nonmarket economic activities is multidimensional and multifactorial have been proposed. Based on this method, the equations of factor effects on labour productivity in two types of economic activity (education and health care) that are important for non-market

services are developed. A comprehensive econometric model of labour productivity in the sector of non-market services in conjunction with national economic development indicators has been suggested. Three blocks of forecast models for estimating the dependence of labour productivity on different factors have been used for calculating the level of growth of labour productivity in the sector of non-market services. The multifactorial dependences of the change in labour productivity on the selected factors were formed in the model and the factor influences to be systematized and the most significant ones to be determined. The obtained quantitative and analytical tools for forecasting labour productivity will improve the effectiveness of state economic policy in non-market services and increase the importance of key macroeconomic indicators of the national economy. 
Keywords: Productivity Forecasting, Labour Productivity, Education and Health Care Sectors, Non-market Services.

\section{References}

1. Azenui, N. B., Rada, C.: Labor productivity growth in sub-Sahara African LDCs: Sectoral contributions and macroeconomic factors. Structural Change and Economic Dynamis 56, 10-26 (2021). doi:10.1016/j.strueco.2020.07.005

2. Besedin, B.: Gross industry product as an indicator of the volume of the inland product of the industry and its productivity. Ukraine economy 1, 31-42 (2009).

3. Blinder, A., Yellen, J.: The Fabulous Decade: Macroeconomic Lessons from the 1990s. (2001).

4. Conti, G.: Training, productivity, and wages in Italy. Labour Economics 12, 557576 (2005). https://doi.org/10.1016/j.1abeco.2005.05.007.

5. Dai, X., Sun, Z.: Does firm innovation improve aggregate industry productivity? Evidence from Chinese manufacturing firms. Structural Change and Economic Dynamics 56, 1-9 (2021). https://doi.org/10.1016/j.strueco.2020.09.005.

6. Dearden, L., Reenen, J., Reed, H.: The Impact of Training on Productivity and Wages: Evidence from British Panel Data. Oxford Bulletin of Economics and Statistics 68, 397-421 (2006). https://doi.org/10.1111/j.1468-0084.2006.00170.x.

7. Donchenko, V., Tarasova, O.: Matrix multiple regression. Bulletin of the Taras Shevchenko National University. Series: Phys.-Math. Science 2, 133-138 (2015).

8. Donchenko, V., Zinko, T., Skotarenko, V.: The concept of a tuple for linear operators and its implementation for matrix tuples. Journal of Computational and Applied Mathematics 3 (120), 127-140 (2015).

9. Duarte, M., Restuccia, D.: The Role of the Structural Transformation in Aggregate Productivity. The Quarterly Journal of Economics 125, 129-173 (2010). https://doi.org/10.1162/qjec.2010.125.1.129.

10.Emelianenko, L., Radionova, I., Fedirko, N.: Macroeconomic assessment of the role of the public sector of the national economy and its deviations in Ukraine from general civilization trends: Analytical note on the results of research work "Crisis 
management of the public sector in macroeconomic instability and threats to the statehood of Ukraine" (state registration number: 0117 U 001196). KNEU, Kyiv (2017).

11.Fagerberg, J.: Technological progress, structural change, and productivity growth: a comparative study. Structural Change and Economic Dynamics 11(4), 393-411 (2000). https://doi.org/10.1016/S0954-349X(00)00025-4.

12.Haller, S.A., Lyons, S.: Effects of broadband availability on total factor productivity in service sector firms: Evidence from Ireland. Telecommunications Policy 43, 11-22 (2019). https://doi.org/10.1016/j.telpol.2018.09.005.

13.Heitz, V. (ed.): Economy of Ukraine: strategy and policy of long-term development. Phoenix, Kyiv (2003).

14.Hrynkevych, S., \& Gural, N Assessment of labour potential renovation for trade enterprises. Economic Annals-XXI, 2016, 160(7-8), 96-99.

15.Ilich, L. Hlushak, O. M., Semenyaka, S. A.: Modeling of employment structural transformations. Financial and credit activity: problems of theory and practice 1(32), 251-259 (2020). https://doi.org/10.18371/fcaptp.v1i32.200469.

16.Ilyash, O., Hrynkevych, S., Ilich, L., Kozlovskyi, S., Buhaichuk, N.: Economic Assessment of the Relationship Between Housing and Communal Infrastructure Development Factors and Population Quality of Life in Ukraine. Montenegrin Journal of Economics 16(3), 93-108 (2020). https://doi.org/10.14254/1800-5845/2020.16-3.8.

17.Ilyash, O.: Strategic priorities of Ukraine's social security concept development and implementation. Economic Annals XXI 7-8, 20-23 (2015).

18.Kinfemichael, B., Morshed, A.K.M.M.: Unconditional convergence of labor productivity in the service sector. Journal of Macroeconomics 59, 217-229 (2019). https://doi.org/10.1016/i.jmacro.2018.12.005.

19.Kocharyan, I., Goritsyna, I., Klymenyuk, M.: Forecasting the use of higher education potential in the post-crisis economy of Ukraine. Bulletin of the National University of Water Management and Environmental Sciences: Coll. Science. wash. Series: Economics 4 (3), 268-273 (2004).

20.Kolbasynsky, S.: Analysis of the economic and mathematical apparatus for modeling and forecasting of state budget performance indicators and macroeconomic 
indicators. Economic Bulletin of the National Technical University of Ukraine "Kyiv Polytechnic Institute" 12, (2015). https://doi.org/10.20535/2307-5651.12.2015.44169.

21.Krugman, P.: The age of diminished expectations: U.S. economic policy in the 1990s. MIT Press, Cambridge, Mass (1994).

22.Kryuchkova, I. (ed.): Macroeconomic modeling and short-term forecasting. Kyiv (2004).

23.Levytska O. O., Mulska O. P., Ivanyuk U., Vasyltsiv T. G., Kunytska-Iliash M., Lupak R. L. Modelling the conditions affecting population migration activity in the Eastern European region: the case of Ukraine. TEM Journal. Vol. 9. Issue 2, 2020.- P. 507-514 (Scopus) DOI: 10.18421/TEM92-12

24.Mulska, O., Levytska, O., Panchenko, V., Kohut, M., Vasyltsiv, T. Causality of external population migration intensity and regional socio-economic development of Ukraine. Problems and Perspectives in Management, 2020, 18(3), pp. 426-437 (Scopus) http://dx.doi.org/10.21511/ppm.18(3).2020.35

25.On approval of the Forecast of economic and social development of Ukraine for 2019-2021: Resolution of the Cabinet of Ministers of Ukraine dated 11.07.2018 № 546, https://zakon.rada.gov.ua/go/546-2018-\%D0\%BF, last accessed 11/17/2020.

26.Sala, H., Silva, J.: Labor productivity and vocational training: evidence from Europe. IZA Discussion Paper 6171, 1-22 (2013).

\section{Cite this paper as:}

Kozhemiakina S., Ilich L., Ilyash O., Hrynkevych S., Kruvysha S. (2021) The Productivity Forecasting in the Sector of Non-market Services (Education and Health Care Sectors): A Case Study of Ukraine. In: Solanki A., Sharma S.K., Tarar S., Tomar P., Sharma S., Nayyar A. (eds) Artificial Intelligence and Sustainable Computing for Smart City. AIS2C2 2021. Communications in Computer and Information Science, vol 1434. Springer, Cham. https://doi.org/10.1007/978-3-030-82322-1_4

URL:https://www.scopus.com/record/display.uri?eid=2-s2.0-

$\underline{85113303543 \& \text { origin }=\text { SingleRecordEmailAlert\&dgcid=raven }}$ sc_affil_ru_ru_email\&txGid=921aca88d2b7c66a6b681be $\underline{68006 \mathrm{c} 28 \mathrm{a}}$

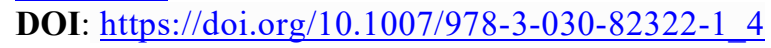

